\title{
Reflections of an Atheist Jew
}

\author{
Leonard Mars
}

School of Social Sciences and International Development, Swansea University, UK

Copyright $(2016$ by authors, all rights reserved. Authors agree that this article remains permanently open access under the terms of the Creative Commons Attribution License 4.0 International License

\begin{abstract}
I was not born nor raised an atheist Jew. My identity was formed by various factors among them family background; geographical migration; British education; secular Zionism; anthropological study and research. These factors were the precipitates of two earlier modern revolutions that transformed the modern world and that affected both Jews and non-Jews, namely the French Revolution which was political, and the Industrial Revolution which was economic. For Jews the French Revolution split the hitherto fused elements of religion and ethnicity into their component parts whilst the Industrial Revolution gave rise to urbanisation and increasing individualism. Jews were faced with a choice of various identities; various permutations were adopted, some apparently paradoxical such as Jewish atheist. In this article I examine the interaction of these factors and document how a single case study, my own, exemplifies but one response to the question of modern Jewish identity. Other Jews have chosen different options. For example, my research in post-communist Hungary has shown that former communist Jews have embraced a number of options. Some founded a Reform Synagogues; others became Hasidim; yet others assumed modern Orthodoxy; a few became Zionists; most, however embraced secular Jewish culture.
\end{abstract}

Keywords Family, Migration, Identity, Religion, Ethnicity, Anthropology

\section{Introduction}

Essentially this paper addresses my Jewish identity. I was not born an atheist but I was born and remain a Jew. How I became an atheist Jew involves discussing the issues of personal and social identity. As we shall see my personal background, especially family and school, and my profession as a social anthropologist combined to make me an atheist Jew. My decision to study anthropology derives to some extent from a childhood curiosity about my family which in fact constitutes an anthropological laboratory. Bear with me while I outline my genealogy, not 12 generations back, like some African tribes, but only two or three.
I was born in Manchester in 1941, the second of four boys, in the Jewish Quarter of Cheetham Hill, but in 1946 we moved to Blackpool where my mother opened a non-kosher boarding house hoping to improve the family's social, economic, educational and health prospects.

I shall start with the paternal side of my family which is less complex than the maternal. My father was born in Salford in the poorest part of the Jewish ghetto, namely Red Bank. His parents were orthodox Jews from Lithuania, then part of Tsarist Russia, who had arrived in England in the 1890s. My grandfather was a shammas i.e. a sexton or caretaker in the synagogue. My father was the youngest of three children whose mother tongue was Yiddish and who only began to speak English when they began school at the age of five. His sister never married and his elder brother in 1931 had a marriage arranged by a shadchan (broker) as was the custom among Orthodox Jews. Again, following Orthodox custom along with his bride he received a dowry. My father's brother had no children, a disaster for an Orthodox Jew and especially for his parents. My father married one year later in 1932, without the aid of a shadchan and without a dowry. His union was based on the idea of romantic love. Ten months later my mother gave birth to my brother, the first grandchild for her in-laws and above all, a son. Needless to say they spoiled him. By the time when I was born, eight years later, my grandparents had died.

My mother was the youngest of ten children born to Jewish parents who had five sons and five daughters. Their first six children were born in Cardiff, the birthplace of my grandfather, whose own mother was a Welsh Baptist who had converted to Judaism in 1859 on her marriage ${ }^{1}$. My maternal grandmother was born in Plymouth to German-Jewish immigrants who arrived in the UK in the 1850s. My mother's parents were anglicised and did not speak a word of Yiddish, hence my mother was monoglot English. Her father was a religious man, nominally Orthodox, and patriarchal as were many of the English bourgeoisie. He was a founder member of the Cathedral Road synagogue in Cardiff and was a dentist by profession. Hence there were

\footnotetext{
${ }^{1}$ The couple was married by Rabbi Solomon Marcus Schiller-Szinessy in the Reform synagogue of The Manchester Congregation of British Jews. For an account of Schiller-Szinessy's subsequent career see Loewe [1].
} 
differences in social class, culture and especially in religiosity between the two families of my parents. When my mother's father settled in Manchester in 1905 he did not dwell in the Jewish quarter. In fact he lived in Ardwick, a largely Irish Catholic quarter with a handful of Jewish families.

Now we turn to the process of assimilation. My mother's five brothers all married Christians, some married Catholics and some married Protestants. Some adopted the faith of their wives. Three of her sisters married Jews and one took an Irish Catholic husband to whom she was married for 62 years. Consequently I have Catholic, Protestant, and Jewish cousins. As a child I naturally wanted to make sense of this diverse family situation and in this sense I was an embryonic anthropologist. I wished to understand the cultural and religious differences within my extended family and also in my interaction with my Christian schoolmates.

Before I elaborate on those differences I should consider the impact of the move from Manchester to Blackpool on my family's Jewish identity. Firstly, we moved out of a largely Jewish neighbourhood into a Christian one. I had attended a state primary school for a couple of weeks in Manchester where most of the pupils and some teachers were Jewish ${ }^{2}$. In Blackpool, I and later my two younger brothers were the only Jews in the school. In Blackpool the family became less religiously observant. For example during the war my mother would exchange her ration of bacon with her Christian neighbours for sugar or eggs. In the boarding house my mother cooked bacon which she had not handled before. She abandoned her entrepreneurial venture after three years and we moved to a lower middle-class, semi-detached house. Three years later my elder brother was doing his national service in the RAF where incidentally he ate his bacon and eggs and sent home his kosher salami to his brothers. ${ }^{3}$

My father did not attend synagogue in Blackpool as regularly as he had done in Manchester. As part of a new venture and a new way of life my mother changed the family name from Margolis to Mars. My mother was a rationalist and a pragmatist and so she told us not to opt out of morning prayers, which were exclusively Christian. But she did advise us not to utter the name of Jesus or to recite the Lord's Prayer.

I and my two brothers attended Hebrew Sunday school (cheder) and further classes two hours after school on Tuesdays and Thursdays, which equipped us for our barmitzvah (a rite de passage that in ritual terms transforms a boy into a man.) We were luckier than my elder brother who went to Revd Balkind's famous cheder six times a week in Manchester. At cheder we learned to read and write biblical Hebrew; the main prayers of the liturgy and the Sabbath service and the major Jewish festivals and fasts All of us abandoned cheder after our barmitzvah and focused on our

\footnotetext{
2 Temple School in Cheetham Hill.

3 Cf. Dan Segre's memoir[2(p.177)] for an account of Palestinian Jews who served in the British Army in WW II and who baffled the military authorities by refusing the kosher meat thoughtfully provided by the catering corps.
}

secular education. Thus it was that I grew up with knowledge of two cultures and two religions in the latter case one to which I subscribed and the other with which I was familiar but not an adherent or participant.

Those who are brought up in a single culture take that weltanschaung for granted, but those who are raised simultaneously with dual or multiple cultures are aware of diversity and a notion of relativity. Let me give you a few examples of these cultural differences from a Jewish perspective.

First, the sabbath day. For Jews it is Saturday, the shabbat, for Christians, unless you are a Seventh Day Adventist, the Jewish Sabbath is very different from the Christian. The shabbat is a sacred day marked off from the rest of the week by rituals which inaugurate and conclude that day from the profane days of the week.

\section{The Calendar}

What constitutes a day in the Hebrew calendar also differs from the Christian since it begins on the eve of a day based on the lunar calendar.

According to the Jewish calendar we are currently in the year 5775 when God created the universe. Of course, the Christian calendar dates from the birth of Jesus 2015 years ago.

A further comment on the Christian year, which states that we are living in 2015 A.D. the year of Our Lord and that Julius Caesar invaded these isles in 54 B.C. (Before Christ). In the late 1940s we Jewish boys and girls in our cheder were referring to C.E. and B.C.E which have now entered more general usage.

\section{Names}

Even as a young boy it used to grate when somebody would ask, "What is your Christian Name?" Only when I grew older would I answer that I did not have one. When I took up my post in the University College of Swansea the official form I filled in asked for my Christian name. I substituted forename, as do the French with prénom. In fact I do have a Hebrew name which is only used in a religious context whenever I am called to read from the Torah. ${ }^{4}$

I shall cite one final cultural difference, although there are many more, and that is the Hebrew alphabet and its script. There are 22 letters in Hebrew which is written from right to left (a benefit for those of you are left-handed, as was my father who at school, was compelled to write with his right hand.) Thus when you start to read a Hebrew book you must turn it over and appear to read from back to front. My daughter tells me that when first invited to a Christian church service she automatically started to read in Hebrew mode.

I must stress here that I am a product of British society and

\footnotetext{
${ }^{4}$ My first computer password was based on my Hebrew name.
} 
that the two cultures I enjoy, and my identity, are different from a French, Russian or Iraqi Jew. Nevertheless qua Jews we share a common tradition.

As modernisation impacts on the developing world, so more and more people become the products of two cultures. Allow me to illustrate this point with one of my favourite, anthropological jokes:-

Two New Guinea natives are sitting in the bush. The first one remarks, "I don't care what they say but when you are hungry nothing is better than a big, fat missionary". The second replies, "Then let's go and bag one." So they take their blowpipes and hunt down, kill, cook, and consume the poor fellow. As they lie back sated the first says, "Yes, when you're starving nothing is better than a big fat missionary". His friend responds, "I know that that is your opinion, but in my considered judgement nothing beats those pork pies we had at LSE."

\section{Identity}

I now turn to the second part of my talk, namely, the issue of identity in general and Jewish identity in particular.

I shall be very brief on the concept of identity. All identities are based on two criteria, one internal and the other external.

The internal involves self-definition, whether that self be an individual or a group. It is self-ascribed. Sometimes this self-definition may be a delusion or a case of wishful thinking best illustrated by this Jewish joke.

Sadie tells her friend Rachel that her son is a ship's captain. Rachel responds, "By him he's a ship's captain; by you he's a ship's captain but is he a ship's captain by sea captains."

Here we see that a claim to an identity must be accepted or validated by significant others - families, friends, neighbours, and communities.

The external criterion is one that is imposed from outside, usually by powerful others, who decree, even against your will, who you are. There may be no personal acceptance or commitment to this label. Thus the Nazi state declared that a person was a Jew even if their parents and grandparents had converted $^{5}$ to Christianity.

\section{Jewish Identity and History}

Jews are an historic people. The term historic is multivalent. In one sense it means that Jews have existed for a long time-too long for the historian, Arnold Toynbee, who described Jews as "living fossils. "[4(p.274)] In a second sense it can mean that Jews are very conscious of their history, and not only their own history have co-existed, fought against, and inter-married. Thus the Jewish calendar is replete with festivals and fasts that have linked Jews to

\footnotetext{
${ }^{5}$ For a Swansea case study see Heini Griffiths' recent book A Haven from Hitler[3] the story of his mother Kate and her family.
}

powerful, foreign civilisations. Here I mention three festivals and one fast:-

Passover, which celebrates the exodus from Pharaoh's Egypt and freedom from slavery. Incidentally this was the meal that Jesus, the Jew, celebrated with his disciples.

Purim, which marks salvation from the ancient Persians.

Chanukah. The Festival of Lights and a victory over the ancient Greeks.

The Fast of Ab.This day marks the destruction of the first Temple by the Babylonians and of the second Temple by the Romans.

In terms of historical consciousness it is significant that the Hebrew bible begins with the word b'reshit, "In the beginning."

A third meaning of the term historic is that Jews have been active in the writing of history, not only their own history as Jews but also the history of the people around them. Jews have been literate for millennia and have been urged to "bear witness" i.e. to record and report and to comment and analyse those recordings. Jews and Jewish identity are bound up with literature, expressed in the phrase that "Jews are the People of the Book."

I now proceed to examine Jewish identity in the modern world especially since the French Revolution (the political revolution) and the Industrial Revolution (the economic revolution). What was happening to Jews in the $18^{\text {th }} \mathrm{C}$ and in the $19^{\text {th }} \mathrm{C}$ was also happening to non-Jews. Thus on the political side we have the emergence of the modern nation state and on the socio-economic side rapid industrialisation and urbanisation. In short the onset of modernity. The impact on Jews was part of a universal phenomenon which was manifest in particular ways among Jews.

This twin development is best captured in the title of J.L.Talmon's book, The Unique and the Universal [5] a set of essays about Jews in the modern world. From this discussion I draw the banal conclusion that the history and the identity of the Jews cannot be looked at in isolation. As we have seen this was just as true in Biblical times as it is in the modern period.

Jewish identity in Europe before the French Revolution was based on the fusion of two elements- a religious element and an ethnic element. Jews were both a people and a religion. The French Revolution split this fused identity into its components. In Western Europe, first in France, full civil rights were bestowed on French Jews so that they became citizens of the French state, members of the French nation as individuals but not as a group. Religion became a private matter-a question of individual conscience. Jews became French men and French women of the Jewish religion, similar to Frenchmen who may be Roman Catholic or Protestant. The ethnic element was de-emphasised and was supposed to wither away. In Eastern Europe in the Russian Empire where most of Europe's Jews resided in the Pale of Settlement, the fusion of religion and ethnicity was to persist. Jews were both a people with a religion and a lingua franca in the form of Yiddish.

I depict the two elements in the following diagram :- 


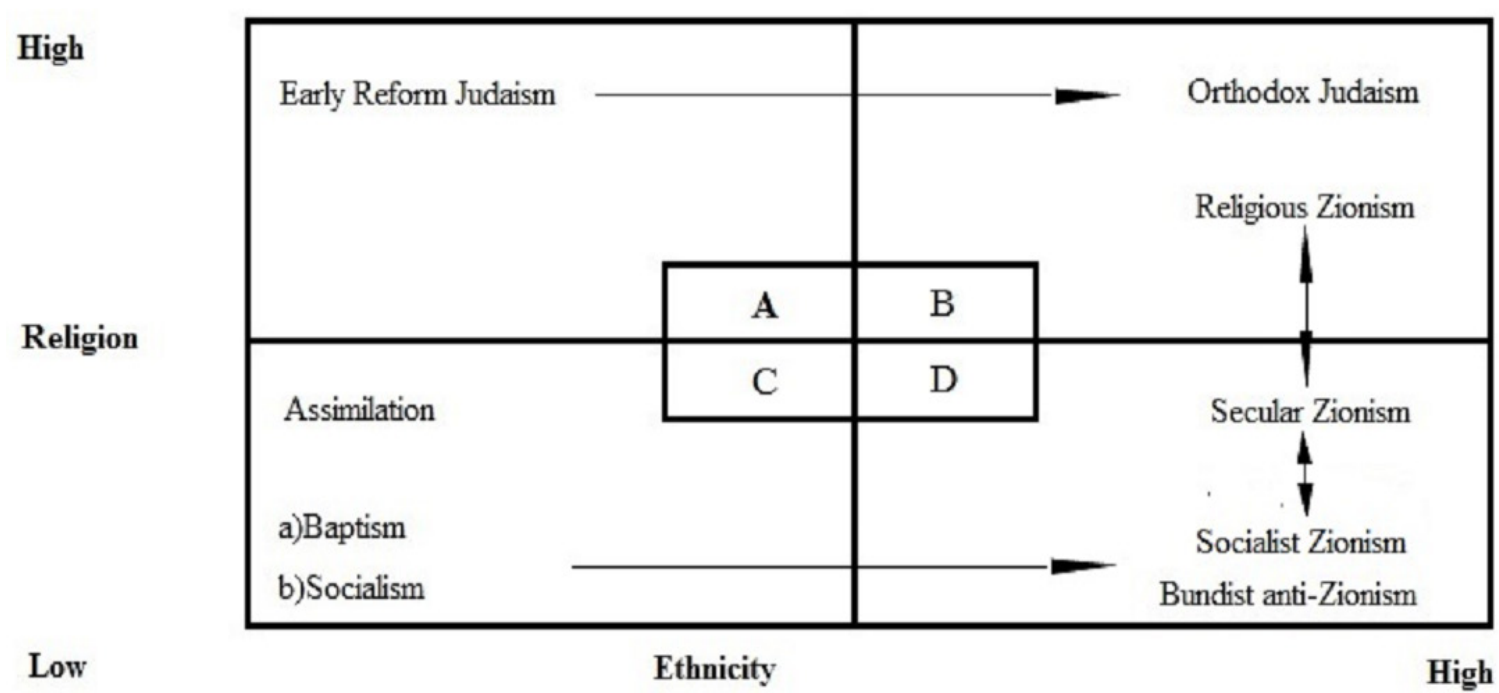

Figure 1. Jewish Identity since the French Revolution.

As the 19thC progressed so Jews were faced with the possibility of choosing an identity whereas in earlier centuries their status was fixed.

After this historical excursus I now turn to my own personal Jewish identity as an atheist Jew. Earlier I discussed my family background and my primary and secondary schooling. I now wish to elaborate on influences outside the home and school and I shall mention two. First, Habonim and second my university degree course which led me to become a professional, academic anthropologist.

I joined Habonim ${ }^{6}$, a secular, Zionist Youth Movement, when I was 15 . It was a scouting organisation but unlike the British scout movement it included girls thereby enhancing, at least for me, its appeal. In addition it was imbued with socialist ideals and its graduates aspired to settle in Israel on the kibbutz. We had a clubhouse in Blackpool where he had various activities sometimes led by a national leader who was based in Liverpool and who had studied at Oxford University. His parents were German Jewish refugees. We learned Israeli songs and dances and some Modern Hebrew. There were discussions on Karl Marx and on theories of socialism, on sociology, and on economics. We were very much a minority both in Blackpool's Jewish community and in Britain at large. Habonim was one of three Zionist youth movements and was not as doctrinaire as the other two. Our rivals were B'nei Akiva, which was religiously orthodox, and Hashomer Hastair, which was decidedly Marxist and atheist.

One consequence of my membership of Habonim was that I acquired a national network of like-minded persons who saw our Jewish identity as cultural and ethnic rather than religious. When I went up to Edinburgh University in 1961 two other freshers from Habonim took up their studies and the three of us acted as youth club leaders to the Edinburgh branch of the movement.

${ }^{6}$ Cf. Kadish[6(p.119-122)] for a brief account of Habonim's foundation and ethos.
When I applied to Edinburgh University in 1959 I had been accepted to read French and Spanish. I was not only interested in the languages but also French and Spanish society and culture. In fact I did not go to university in 1959 but worked for two years in the British Civil Service during which time, influenced by my elder brother Gerald, I discovered Social Anthropology, the comparative study of societies and cultures and so I switched courses. ${ }^{7}$

Most anthropologists are atheists (the few who were not were Roman Catholic among them the former communist, Victor Turner, who became a Catholic. Another convert was Sir Edward Evans-Pritchard, the Professor at Oxford).

Among the sociological and anthropological writings that influenced me were the theorists, Marx, Durkheim and Weber. Durkheim's great masterpiece, The Elementary Forms of the Religious Life [8], published five years before his death, reinforced my thoughts about religion. Durkheim, an atheist, was the son of a rabbi who argued that God was a human construct. Unlike Marx, who dismissed religion as a form of "false consciousness" which served the interests of ruling elites in order to control those under them, Durkheim argued that religion, especially through its rituals instilled a sense of community and of social and moral values. In short he saw that religion had a function for society at large.

Becoming an anthropologist alerted me to the existence of alternative modes of life and, in particular, of different types of religious beliefs and practices. In turn such study reinforced understanding of religion. In addition, by entering the profession of academic anthropology I found myself in a community of like-minded persons with an occupational culture that was tolerant of social and cultural difference and where it was acceptable to be an atheist Jew.

Moreover, it is a profession that has enabled me through my teaching and research, to investigate and think about

\footnotetext{
${ }^{7}$ The book that converted me to Social Anthropology was Max Gluckman's Custom and Conflict in Africa [7]. Gluckman later became the supervisor of my doctoral thesis.
} 
things Jewish and thereby maintain my commitment to Yiddishkeit.

Earlier I observed that one's identity is both self asserted but that such an identity must be validated by others, How these others perceive the individual can confirm or reject the claim to an identity. My experience, both as a schoolboy and as an anthropologist, demonstrates some of these external perceptions. For example, I have mentioned that at primary school I attended the morning assembly that was characterised by an act of Christian worship in which I was a passive participant. When I first went to the secondary school I continued that practice until a couple of days later, at the end of the prayer service, a prefect was despatched to summon a group of about thirty boys who trooped into the hall. I asked my neighbour who were these boys. He informed me that they were the Jews. Whereupon I responded that I must join them.

Later that first week I joined my first Religious Education class where the lesson was taken by a teacher who was an Anglican minister. He asked, "Are there any Jews in this class?" I put up my hand and a murmur went round the room. "He's a Jew, a Jew." The murmur was one of surprise and disapproval and elicited from a boy who sought to sympathise with my status, "It's not his fault, he can't help it." The teacher then declared, "Then we'll have to study the Old Testament."

During my village fieldwork in Israel, Where I was the only English person I was initially defined as the "Englishman" and was registered as such in the village store. Later, because I remained there during the Six Days War I became more accepted though several villagers could not understand why, since I was a Jew, I had not been mobilised into the Israeli army. Gradually my identity was transformed from that of a stranger to one of a friend and neighbour.

Now for a few concluding thoughts.

If I reject the religious element of my Jewish identity how can I call myself a Jewish atheist? In my opinion I am Jewish by virtue of my ethnic and cultural situation. In terms of my diagram I clearly fit into the category of Jew who is high on the ethnicity pole and low on the religion dimension, at least in terms of belief and faith. From my perspective Judaism does not rate belief as strongly as Christianity, rather it sets store on practice, and furthermore, on identification with the Jewish people. My own religious practice or observance is selective but my identification with fellow Jews is stronger. For example, living as I do in a small, and diminishing, provincial Jewish community has impelled me to participate in its social and religious life which is based on its synagogue of which I am a member. I attend Sabbath evening services and on major festivals. Nor am I the only member who is a non-believer since there are four or five other congregants of similar opinion. If a member of the congregation informs me that he has to recite Kaddish, (prayers for dead relatives) and asks me to make up a minyan, then I feel an obligation to attend. Because of the precarious position of the Swansea community I feel I should try to keep it going and as such it requires participation in religious services. I should point out that when I lived in larger Jewish communities whether in Israel, Manchester or Edinburgh then I rarely attended acts of worship.

The institution of the minyan clearly indicates the communal element in the Jewish religion.

As part of my identification with the Jewish people I attend synagogue on Yom Kippur (The Day of Atonement). Significantly on that day congregants do not pray that I have sinned but that "We have sinned".) Again, the prayer is collective not individual.

Unlike many atheists I have a love of the Hebrew Bible and its language, which I read in English and in Hebrew as literature.

Indeed I have published an anthropological paper entitled, "What Was Onan's Crime?"'[9] In a sense I sought like some ancient and modern rabbis and scholars to analyse biblical texts but from an anthropological perspective

In this respect I am alongside the great Israeli writer Amos $\mathrm{Oz}$ who together with his daughter, Fania Oz-Salzberger, wrote a book three years ago entitled jews and words[10] from which I quote the following two excerpts.

"As Jewish atheists, we take religion to be a great human invention.

As such it is neither falsehood nor forgery." (43).

Finally, referring to the Hebrew scriptures, they write,

We don't like all of it. We don't ascribe either historical factuality or scientific certainty to much of it. We are not morally bound by any of it. But we find much that is true, good, and insightful [in parts of the Jewish bookshelf,] that we can claim to have replaced faith with wonder. ( 43:44)

In conclusion I am more than content to align myself with the Ozs and with others such as Primo Levi and Sigmund Freud, like them both Jewish and atheist. Furthermore several anthropologist among them my teacher, Max Gluckman, were Jewish atheists and committed Jews.

Finally, I conclude with a statement by the artist Josef Herman, "I am Jewish, whether I like it or not. And, moreover, I like it." [10]

\section{Acknowledgements}

This paper was presented to the annual conference of The British Association of Jewish Studies held in Manchester in July 2015.

I delivered an earlier version of this paper to the Swansea Humanist Association. I am grateful to its chairman, Brian Cainen, for his invitation to address the group.

I appreciate the critical reading and constructive comments of my colleague, Hilary Stanworth, on an earlier draft.

Thanks to my cousin, Gareth Abel, for his genealogical research on our family's history. 


\section{REFERENCES}

[1] Loewe R. Solomon Marcus Schiller-Szinessy, 1820-1890. Transactions of the Jewish Historical Society of England. 1968; 21: 148-89.

[2] Segre DV. Memoirs of a fortunate Jew. London: Peter Halban; 1987.

[3] Griffiths H. A Haven from Hitler. Talybont: YLolfa; 2014.

[4] Toynbee A. A Study of History. Volume VIII. Oxford: Oxford University Press; 1954.

[5] Talmon JL. The Unique and the universal. London: Secker and
Warburg; 1965.

[6] Kadish S. 'A Good Jew and a Good Englishman' The Jewish Lads' and Girls' Brigade 1895-1995. London: Valentine Mitchell; 1995.

[7] Gluckman, M. Custom and Conflict in Africa. Oxford: Blackwell; 1956.

[8] Durkheim E, The Elementary forms of the religious life. New York: Free Press; 1915.

[9] Mars L. What Was Onan's Crime? Comparative Studies in Society and History. 1984; 26(3): 429-39.

[10] Oz, A, Oz-Salzberger F, Jews and words. New Haven: Yale University Press; 2012.

[11] Herman J, Bohm-Duchen M. A Jewish artist among the miners. Jewish Quarterly. 1998; 45(2): 54-8. 